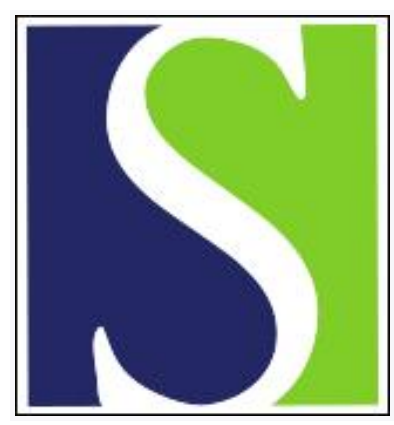

Scand J Work Environ Health 1989;15(5):335-338

https://doi.org/10.5271/sjweh.1841

Issue date: Oct 1989

Association between acid fumes in the work environment and dental erosion.

by Tuominen M, Tuominen R, Ranta K, Ranta H

Affiliation: Department of Cariology, University of Helsinki, Finland.

This article in PubMed: www.ncbi.nlm.nih.gov/pubmed/2799320

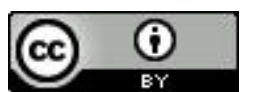




\title{
Association between acid fumes in the work environment and dental erosion
}

\author{
by Maija Tuominen, DDS, ${ }^{1}$ Risto Tuominen, $\mathrm{PhD},{ }^{2}$ Kari Ranta, $\mathrm{PhD},{ }^{1}$ Helena Ranta, $\mathrm{PhD}{ }^{1}$
}

\begin{abstract}
TUOMINEN M, TUOMINEN R, RANTA K, RANTA H. Association between acid fumes in the work environment and dental erosion. Scand J Work Environ Health 1989;15:335-338. The effect of inorganic acid fumes from the work environment on the erosion of teeth was studied blindly. A sample of 186 workers was drawn from four factories. Among the 157 dentulous participants, 76 were working in departments containing acid fumes, and 81 had never worked under such conditions and were used as referents. Of the acid workers $18.4 \%$ had one or more teeth with erosion, and the corresponding figure for the referents was $8.6 \%$. With a longer duration of exposure the proportion of subjects with erosion increased. The acid workers had more teeth with erosion than the referents, especially upper anterior teeth. The findings suggest that even today exposure to inorganic acid fumes from the work environment may increase the erosion of teeth, especially the upper anterior teeth, which are not continuously protected by saliva and the lips.
\end{abstract}

Key terms: inorganic acid fumes, teeth.

Loss of hard dental tissue from tooth surfaces may be caused by physical agents (abrasion and attrition) or by chemical agents without bacterial involvement (erosion). It has been suggested that, when the loss is excessive and likely to affect the appearance or function of the dentition or to cause discomfort or pain, it should be considered pathological (1).

Lesions of noncarious origin may be formed in hard dental tissue as a result of the corrosive action of any one of a number of chemical substances (2). The most extensively studied substances which cause chemical decalcification are the inorganic acids.

Several previous reports indicate that damage may occur to hard oral tissues as a result of occupational hazards. Decalcification of the teeth of chemical workers employed in the manufacture of acids was reported as early as 1915 (3). Investigations of dental erosion among industrial workers have been limited to observations on the effects of hydrochloric and picric acids (4), nitric and sulfuric acids (5), tartaric acid (6), and sulfuric acid (7). ten Bruggen Cate (8) and Sandin (9) examined workers exposed to several different acids. In all these studies dental erosion was found among the acid workers, especially on anterior teeth. Malcolm \& Paul (7), ten Bruggen Cate (8), and Sandin (9) included a reference group in their studies, but the examiners knew which subjects were acid workers and which were referents.

The aim of our present study was to determine whether dental erosion is more prevalent and more se-

\footnotetext{
Department of Cariology, University of Helsinki, Helsinki, Finland.

2 Department of Public Health, University of Helsinki, HeIsinki, Finland.
}

Reprint requests to: Dr M Tuominen, Department of Cariology, Mannerheimintie 172, SF-00300 Helsinki, Finland. vere among workers occupationally exposed to inorganic acid fumes than among referents.

\section{Subjects and methods}

A sample of 186 male workers was drawn from two battery factories (Akkuteollisuus Ltd in Espoo and Pakkasakku Ltd in Vantaa) and from two galvanizing factories (Outokumpu Ltd in Harjavalta and Kokkola) in Finland. The mean age of the acid workers was 38 (range 19-57) years, and that of the referents was 39 (range 22-55) years. The companies were chosen because they were known to employ workers exposed to inorganic acid fumes almost continuously and also workers in acid-free departments. Sulfuric acid was the most common acid to which the workers were exposed. Altogether 92 acid workers and 94 referents were included in the sample. Eleven of the acid workers and five of the referents did not participate in the survey.

The referents were from acid-free departments of the same companies at which acid workers were employed. No worker was accepted as a referent if he had at any time worked in a department containing acid fumes during his present or previous employment.

The sulfuric acid concentrations in the air of all the factories had been measured by the Institute of Occupational Health. The measurements and exposure conditions are summarized in table 1.

The survey was carried out during November and December 1986. The subjects from Pakkasakku Ltd were examined at the Department of Cariology, University of Helsinki. All the others were examined in a mobile dental unit at the occupational health station located at the factory where they worked.

In the examination the teeth were thoroughly dried with air and examined in good light. A mouth mirror 
and an explorer were used. All five surfaces of the teeth were diagnosed separately. During the pilot study all clinical recordings of dentition were made by two dentists in order to ensure acceptable interexaminer repeatability. Our findings are based on the clinical recordings of one dentist. The dentists were unaware of the exposure status of the subjects.

In this study attrition was defined as loss by wear of tooth substance from mastication or contact be-

Table 1. The sulfuric acid concentrations $\left(\mathrm{mg} / \mathrm{m}^{3}\right)$ at the four factories in 1971-1986.

\begin{tabular}{|c|c|c|c|c|}
\hline Year & Espoo ${ }^{a}$ & Vantaa $^{b}$ & Harjavalta ${ }^{c}$ & Kokkola $^{d}$ \\
\hline 1971 & $\ldots$ & 0.34 & $\ldots$ & $\ldots$ \\
\hline 1972 & $\ldots$ & $\ldots$ & $\ldots$ & $\ldots$ \\
\hline 1973 & $\cdots$ & 0.15 & 0.80 & 0.67 \\
\hline 1974 & $\ldots$ & & $\cdots$ & 0.42 \\
\hline 1975 & . & 0.07 & $\cdots$ & 0.67 \\
\hline 1976 & $\cdots$ & . & $\cdots$ & 1.08 \\
\hline 1977 & $\ldots$ & $\ldots$ & 1.60 & 0.52 \\
\hline 1978 & 2.00 & $\ldots$ & $\cdots$ & 0.43 \\
\hline 1979 & . & . & 0.30 & 0.47 \\
\hline 1980 & $\ldots$ & $\ldots$ & $\ldots$ & 0.65 \\
\hline 1981 & 0.81 & $\ldots$ & $\ldots$ & 0.48 \\
\hline 1982 & $\ldots$ & .. & . & 0.41 \\
\hline 1983 & . & $\ldots$ & . & 0.44 \\
\hline 1984 & 1.06 & $\ldots$ & 0.55 & 0.55 \\
\hline 1985 & 0.10 & 0.63 & 0.60 & 0.60 \\
\hline 1986 & 0.06 & 0.40 & 0.54 & \\
\hline
\end{tabular}

a Exposure conditions: forming; lead battery plates are immersed in tanks of dilute sulfuric acid and charged by means of electric current.

b Exposure conditions: forming, charging; finished batteries are filled with acid and charged by means of electric current

c Exposure conditions: nickel in dilute sulfuric acids is turned into nickel cathode by means of electrolysis.

d Exposure conditions: roasting; zinc sulfide is converted into acid-soluble zinc oxide; as a by-product sulfur dioxide gas is produced, which is further processed to sulfuric acid.

Table 2. Percentage of subjects and teeth with erosion among the acid workers and the referents in relation to exposure time.

\begin{tabular}{ccccc} 
Group & $\begin{array}{c}\text { Number } \\
\text { of } \\
\text { subjects }\end{array}$ & $\begin{array}{c}\text { Exposure } \\
\text { time } \\
\text { (years) }\end{array}$ & $\begin{array}{c}\text { Subjects } \\
\text { with } \\
\text { erosion } \\
(\%)\end{array}$ & $\begin{array}{c}\text { Teeth } \\
\text { with } \\
\text { erosion } \\
(\%)\end{array}$ \\
\hline
\end{tabular}

\begin{tabular}{llrrr}
$\begin{array}{l}\text { Acid workers } \\
\text { Half with the longest }\end{array}$ & 37 & $\geq 13$ & 23.0 & 5.1 \\
$\begin{array}{l}\text { exposure time } \\
\text { Quarter with the longest } \\
\text { exposure time }\end{array}$ & 18 & $\geq 16$ & 22.2 & 5.4 \\
All & 76 & $1-39$ & 18.4 & 3.7 \\
Referents & 81 & $\cdot$ & 8.6 & 2.1 \\
\hline
\end{tabular}

Table 3. Prevalence of erosion according to grade (Eccles classification) $)^{a}$ and work status.

\begin{tabular}{lcc}
\hline & $\begin{array}{c}\text { Acid workers } \\
(\%)\end{array}$ & $\begin{array}{c}\text { Referents } \\
(\%)\end{array}$ \\
\cline { 2 - 3 } Grade 1 & 11.8 & 6.2 \\
Grade 2 & 11.8 & 4.9 \\
Grade 3 & 2.6 & 0.0 \\
\hline
\end{tabular}

a See the Methods section for a definition of the different grades.

$P=0.001$ (statistical evaluation between acid workers and referents with the trend test: chi-square $=6.5$ ). tween occluding or approximal surfaces. Erosion was considered loss of tooth substance by chemical process without bacterial involvement. The erosion lesions were graded for severity according to the classification of Eccles \& Jenkins (10) as follows: grade 1: loss of surface features of the labial, lingual, or occlusal enamel surface, giving a smooth, glazed appearance and not involving the dentine; grade 2 : involvement of the dentine for less than one-third of the area of the tooth surface; and grade 3: involvement of the dentine for more than one-third of the area of the tooth surface.

Among the participants were 157 dentulous workers who were included in these analyses. The trend test (11), the chi-square test, and the rate ratio (RR) (12) were used for the statistical analyses.

\section{Results}

The acid workers had an average of 20.5 (range 2-32) teeth remaining, and the referents averaged 20.1 (range $5-32$ ) teeth. The mean numbers of carious teeth were 2.0 and 1.7 , respectively. These differences were not statistically significant.

One or more teeth with erosion were found among $18.4 \%$ of the acid workers and $8.6 \%$ of the referents (RR 2.1, P<0.075). Of the acid workers' teeth, $3.7 \%$ had erosion, and for the referents the corresponding figure was $2.1 \%$ (RR 1.8, P<0.008) (table 2$)$. In the next stage of the analysis the occurrence of erosion among all the referents was compared with that of the acid workers, first with half and then with one-fourth of the acid workers with the longest duration of exposure. The occurrence of dental erosion was found to be significantly higher among the acid workers with prolonged exposure times than among the referents. However, when the data of the subjects with the

Table 4. Numbers of teeth with erosion and attrition in the upper and lower jaws of the acid workers and referents according to tooth position. ${ }^{a}$

Acid workers
$\begin{aligned} & \text { Anterior } \\ & \text { teeth }\end{aligned}$


longest exposure time were analyzed, no additional occurrence of erosion was observed (table 2).

Erosion of all three grades of Eccles' classification were found significantly more often among the acid workers than among the referents (table 3).

The acid workers had significantly more teeth with erosion in the upper jaw than did the referents $(\mathrm{P}<0.001)$, but this finding did not apply to the lower jaw (table 4). The teeth with erosion were generally in the upper and lower anterior region among both the acid workers and the referents. The acid workers had $8.0 \%$ of their upper anterior teeth with erosion, and the corresponding figure for the referents was $2.6 \%$ $(\mathrm{P}<0.01)$. The respective percentages for the lower anterior teeth were 3.5 and $2.9 \%$ (table 4 ).

The referents had significantly more teeth with attrition in the upper jaw than did the acid workers ( $P<0.001)$, but this finding did not apply in the lower jaw (table 4). The acid workers had $63.8 \%$ of their upper anterior teeth with attrition, and the corresponding figure for the referents was $72.5 \%(\mathrm{P}<0.013)$. The respective percentages for the lower anterior teeth were 78.6 and $77.4 \%$ (table 4 ).

\section{Discussion}

The drop-out from the survey can be considered small; $91.4 \%$ of the subjects attended the survey. The referents participated in the survey more often than the acid workers did. The survey was carried out during normal workhours, although a limited number of shift workers were examined outside their workhours. In these cases the workers either had to wait at the factory or had to come back to the workplace to attend the survey. Because of the small drop-out the results can be regarded as representative of the studied groups.

The referents were chosen from the same factories as the acid workers, and they came from the same socioeconomic groups as the acid workers. In the study of Sandin (9) the workers from three different factories were examined, and harbor workers were used as the reference group. ten Bruggen Cate (8) examined subjects from 48 companies in his study, and his referents were chosen from the same companies. The factories in our survey were located in different parts of Finland, and therefore local circumstances are unlikely to have affected the results. By drawing the referents from the same factories as the acid workers and carefully ensuring that they had never worked in departments containing acid fumes, we were able eliminate the effects of environmental factors other than acid fumes.

The examiners were unaware of the exposure status of the subjects. We were therefore able to determine the effect of acids without letting the examiners' subjective expectations influence the results. In the earlier studies (5-9) the clinical examiners knew whether the subject belonged to the reference or acid worker group, and no blind arrangements were made.
The loss of hard dental tissue can be due to gradual erosion by the direct impingement of acid fumes on the exposed tooth surfaces. The earlier finding that teeth showing erosion are generally in the upper and lower anterior region $(4,5,7,8,13-16)$ was confirmed by our study (table 4 ). The site of erosion suggests the direct action of acid fumes on the teeth exposed during talking or during breathing through the mouth. The premolars and molars are apparently protected by the salivary wash, and this finding suggests that an increased salivary flow may assist in protecting the dentition (5).

Because several classifications of erosion have been used in the various studies, it is difficult to compare the different findings. Although in our study the acid workers more often had different grades of erosion, the acid concentrations in the air were low. Thus it seems that exposure to inorganic acid fumes is clearly related to dental erosion, a finding that suggests the presence of an occupational hazard. Possible reasons for erosion among the referents include dietary habits (coarse food or excessive consumption of acidic fruits and juices) or intrinsic factors (regurgitation of gastric contents or recurrent vomiting).

ten Bruggen Cate (8) reported that attrition occurred among $12.8 \%$ of the studied acid workers and $7.5 \%$ of the referents. In our study $85.5 \%$ of the acid workers and $92.6 \%$ of the referents had attrition. One possible explanation for the observed differences could arise from the interpretation of diagnostic criteria. It is sometimes difficult to make a distinction between erosion and attrition.

Previous studies have suggested a relationship between the occurrence of erosion in departments containing acid fumes and length of exposure $(5,7,8,15)$. Also in our study the severity of erosion seemed to increase with prolonged time of exposure to inorganic acid fumes (table 2).

Lynch \& Bell (5) found that employed workers wearing mouth masks had dental erosion significantly less often than those not using such a mask. However, the employment time in that study was short ( 1 month-3.5 years), and the development of dental erosion within such short periods of time can be expected only under heavy exposure.

The information on the wearing of a mouth mask at the factories included in this study was conflicting and depended on the worksite and source. Mask types included those with plain or woven filters and those connected with a fresh air supply. Masks have been found to be somewhat uncomfortable to wear for longer periods of time, and people tend to avoid using them. Ventilation of the worksite, together with regular use of mouth masks, may be an effective measure in the prevention of dental erosion. Installation of efficient exhaust systems, redesign of equipment removing acid fumes from workers' breatining air, and the use of local exhaust hoods are examples of ways of improving the work environment. 
According to the measurements made by the Institute of Occupational Health the concentrations of sulfuric acid fumes have varied from 0.06 to $2.0 \mathrm{mg} / \mathrm{m}^{3}$ in the studied factories (table 1). Malcolm \& Paul (7) reported the sulfuric acid concentration in the air to be $0.8-16.6 \mathrm{mg} / \mathrm{m}^{3}$ in their study. Significantly higher sulfuric acid concentrations than those of our study may partly explain their higher numbers of subjects with dental erosion. Occupational health legislation has undergone considerable changes in industrialized countries since the study of Malcolm \& Paul (7). It may well be that exposure at currently allowable concentrations does not cause visible effects within the same period as earlier.

One should be cautious when generalizing the findings of the present or previous studies. It is possible that different dental care habits, nutrition, and other factors have an adverse effect on dentition concomitantly with acid fumes. Thus the differences found when only the effect of acid fumes is analyzed can be different when the effects of other factors are simultaneously controlled.

\section{Acknowledgments}

The authors wish to thank Drs A Saraste and H Salusjärvi for their technical assistance and the Finnish Work Environment Fund for its financial support.

\section{References}

1. Eccles JD. Tooth surface loss from abrasion, attrition and erosion. Dent Update 1982;9:373-81.
2. Boyes J, Hartles RL, Slack GL, Stones HH, Steel J. Memorandum on the erosion of teeth. Br Dent J 1959; 106:239-42.

3. Anonymous. Recognizing vocations from the teeth. Sci Am 1915;79(suppl 2053):300.

4. Berenzon FB. The effect of acids on the teeth in chemical industries. Br Dent J 1931;52:22.

5. Lynch JB, Bell J. Dental erosion in workers exposed to inorganic acid fumes. Br J Ind Med 1947;4:84--6.

6. Elsbury WB, Browne RC, Boyes J. Erosion of teeth due to tartaric acid dust. $\mathrm{Br} \mathrm{J}$ Ind Med 1951;8:179-80.

7. Malcolm D, Paul E. Erosion of the teeth due to sulphuric acid in the battery industry. $\mathrm{Br} \mathrm{J}$ Ind Med 1961;18: $63-9$.

8. ten Bruggen Cate HJ. Dental erosion in industry. $\mathrm{Br} \mathbf{J}$ Ind Med 1968;25:249-66.

9. Sandin G. Tandhälsotillståndet hos arbetare vid tre syrafabriker [Dental health among workers at three acid producing factories] [Dissertation]. Helsingborg (Sweden): Tandhalsovard AB, 1981. $215 \mathrm{p}$.

10. Eccles JD, Jenkins WS. Dental erosion and diet. J Dent 1974;2:153-9.

11. Nurminen $\mathbf{M}$. Analysis of trends in proportions with an ordinally scaled determinant. Biom J 1986;28:965-74.

12. Miettinen $\mathrm{O}$, Nurminen M. Comparative analysis of two rates. Stat Med 1985;4:213-26.

13. Paul E. Erosion of the teeth due to industrial sulphuric acid. Dent Mag Oral Top 1962;79:137-43.

14. Schour I, Sarnat BG. Oral manifestations of occupational origin. JAMA 1942;120:1197-207.

15. Skogedal O, Silness J, Tangerud T, Laegreid O, GilhuusMoe O. Pilot study on dental erosion in a Norwegian electrolytic zinc factory. Community Dent Oral Epidemiol 1977;5:248-51.

16. Simpson RS. Action of the acids on the teeth of workers in high explosive factories. Dom Dent J 1919;31: $94-7$.

Received for publication: 1 March 1989 